to the Department of Mineralogy through his friend IIr. G. Leslie Wates. Further gifts of tourmaline, sapphire and hamate from Burma have been mado by Mr. A. C. D. Pain. A new find of tektites, small glass bodies of curious shape and unknown origin, has recently been made in Texas and a fow good specimens have been acquired by exchange with the University of Texas. Also a slice of the Now South WVales meteoritic stone Narellan, new to the Museum collection, has been acquired by exchange with the Australian Museum. Among the few purchases approved by the Trustees aro included two good crystals of olivine from the Red Sea, and some parti-coloured tourmalines and cordierito from Brazil. The Department of Botany has received about 1,750 plants from North Burma and Assam collected by Captain F. Kingdon Ward on his latest expedition. Ho visited China intending to proceed to the Shan States and south-west Yunnan, but after six weeks (a month of which was spent under open arrest) ho left China and went to North Burma. In 1938 he spent six months in the Eastern Himalayas and then joined the Vernay-Cutting expedition to the Burma-China frontier.

\section{Electric Propulsion at Sea}

A. C. HARDY, in the Electrician of October 13, discusses tho part that electrically propelled ships are likely to play in tho present conflict, and whether this is likely to have a great effect on the future of electrically propelled and Diesel-electric ships. A number of coasters use Diesel generating power not only for propulsion but also largely for winches, windlass and other ancillary purposes. In Amsterdam, turbo-electric vessels are being built and they are now fitting out a pair of 'units' with a special method of propulsion. One of these two ships is the passenger and cargo turbo-electric vessel Josef Stalin, designed by the Netherlands Shipbuilding Co. for the Soviet Government, in accordance with the requirements of the U.S.S.R. Shipping Register. This vessel and her sister ship have accommodation for 48 first-class, 164 second, and 296 third-class passengers and also a crew of 102. They have a length of about 133 motres overall with a beam of 18.5 metres, a depth of 9.65 metres and a gross tonnage of about 7,500. It is stated that their turbo-generators deliver about 14,000 s.r.P., to the two shafts. In this respect, on two screws the new ship will develop within 1,000 h.p. of the maximum output of the big German liner Patria, the largest Diesel-electric ship afloat. The Josef Stalin and her sister ship are expected to have a speed of about 20 knots and they will be among the fastest electric ships in existence. Three large turbo-electric all-welded vessels which were launched recently in the United States have made a great step in advance by using very high pressure and very high temperature steam. If the future should show that thero will bo a demand for Diesel engines applied to ships having even higher powers than thoy have at present, it looks as if the struggle for supremacy would lie between Diesel-electric A.C. drive and Diesel-geared drive.

\section{Recent Earthquakes}

Dr. G. VAN DiJk of the De Bilt (Holland) seismological observatory recorded fifteen large earthquakes during August and fourteen during September 1939. One of the largest recorded at De Bilt was that of August 3, which probably had an epicentre $2,350 \mathrm{~km}$. from Do Bilt in an approximately easterly direction. Preliminary determinations of epicentres have been made by the United States Coast and Geodetic Survey in co-operation with Scienco Service and the Jesuit Seismological Association showing the earthquake of August 12 to have been in the north Pacific Ocean off Japan, that of August 24 in the Pacific Ocean near Central America, and that of August 26 in the Pacific Ocean near tho New Hebrides. The somewhat deep focus $(60 \mathrm{~km}$.) earthquake of September 8 had an epicentro in lat. $51^{\circ} \mathbf{N}^{\top}$., long. $175^{\circ} \mathrm{E}$., just south of the Andrean Islands, which are part of the Aleutian Islands. This was near the epicentre of the very strong 'missing earthquake' of November 10, 1938. The shock of September 21 had its epicentre near the island of San Luis in the Gulf of California in a region which is liable to small earthquake shocks. Kow reported that six strong earthqualies were registered on the seismograplis during Soptember, the latest to bo recorded being on October 10, with a possiblo epicentral distance of $88^{\circ}$ and rather deep focus (75 km.).

\section{Forestry Abstracts}

The Imperial Forestry Bureau at Oxford has commenced the issue of a publication entitled Forestry Abstracts. The lines upon which this quarteriy journal, as it is designated, are based, follow those of the well-known Experiment Station Record of the United States Department of Agriculture, which is now in its eightieth volume. This latter publication is not, however, confined to forestry. Forestry Abstracts is intended to record in tho English language brief reviews and précis of the current forestry literature of the world. The general idea is that each issue will include short reviews of literature in different branches of forestry, with notes on annual forestry reports, and abstracts classified by subjects. "In the abstracts the aim is to epitomize the contents of each paper so as to enable the reader to judge of its value as a contribution to knowledge". The subject headings are as follow : General Forestry ; Fundamental Natural Laws of the Forest; Treo Species; Forest Botany; Forest Zoology ; Sylviculture; Utilization; Technology ; Protection; Increment, Yield; Management; Working Plans, Surveys ; Economics ; Administration ; Policy.

\section{Indian Journal of Entomology}

WE have received a copy of the first issue of a new zoological periodical entitled the Indian Journal of Entomology (vol. 1, pts. l and 2. June 1939). This journal is to be published twice a year by the Entomological Society of India and the subscription price abroad for non-members of that Society is Rs. 16 per annum. All communications should be addressed to the General Secretary, Entomological Socioty of 